\title{
Stent placement after flexible ureterorenoscopy for renal stones can improve stone-free rate on final follow-up: A retrospective single center study
}

\author{
Böbrek taşlarına uygulanan fleksibl üreterorenoskopi sonrası stent yerleştirilmesi son takipte taşsızlık \\ oranını arttırabilir: Retrospektif tek merkezli çalışma
} Onur Kaygısız ${ }^{1}$, Gökhun Özmerdiven ${ }^{2}$, Kadir Ömur Günseren ${ }^{1}$, Hakan Kılıçarslan ${ }^{1}$

\begin{abstract}
Aim: Although the advantage of ureteral double $\mathrm{j}(\mathrm{D} / \mathrm{J})$ stenting has been shown in reducing post- operative pain after ureteroscopic surgery, its contribution to stone clearance for additional treatment has not been fully assessed. In this study we aimed to evaluate the effect of stenting on stone free rates at the end of the additional treatment.

Methods: We reviewed the medical records of all patients who underwent flexible ureterorenoscopy (FURS) for kidney stones between October 2009 and January 2015. Patients with malignant ureteral stricture, severe skeletal malformation, renal unit malformation, non-opaque renal stone or lost to follow-up were excluded. 47 of 289 patients (stenting 24 patients, non-stenting 23 patients) assessed. The perioperative and postoperative parameters and stone-free rates were compared in patients whether they had intraoperative $\mathrm{D} / \mathrm{J}$ stent (group 1) or not (group 2).

Results: No differences were found between groups according to age, gender, body mass index, operation history, preoperative stenting history, shockwave lithotripsy history, ureteral stricture, stone size, access sheath rate, retreatment, or additional treatment number and stone location. Operation time was significantly higher in group 1. Those who refused additional treatment were insignificantly lower in group 1. Although the stone-free rates were similar for the two groups at the end of the first month, the stone-free rates after the additiona treatments were significantly higher in group 1 .
\end{abstract}

Conclusion: Stenting during FURS, improved the stone-free rate on final follow-up, if residual stones remain. Keywords: Stents, kidney stone, ureteroscopy

Öz

Amaç: Her ne kadar üreteroskopik cerrahi sonrası üreteral çift $\mathrm{J}$ uçlu (Double $\mathrm{J}-\mathrm{D} / \mathrm{J}$ ) stent yerleştirilmesinin postoperatif ağrıyı azaltmaktaki avantajı gösterilmiş olsa da taşların temizlenmesi ve ek işlem için hasta uyumuna etkisi tam olarak değerlendirilmemiştir. Biz bu çalışmada stent takılmasının ek tedaviler sonunda taşsızlık oranlarına olan etkisini araştırdık.

Yöntem: Kasım 2009 ve Ocak 2015 tarihleri arasında fleksibl üreterorenoskopi (FURS) uygulanan hastaların tıbbi kayıtları gözden geçirildi. Maling üreteral darlık, ileri derecede iskelet malformasyonu, böbrek malformasyonu olan hastalar ve takipten çıkan hastalar çalışmadan çıkarıldı. 289 hastanın 47'si (24 stent takılan, 23 stent takılmayan) değerlendirilmeye alındı. Operasyon sırasında D/J stent takılan (grup 1) ve takılmayan (grup 2) hastaların perioperatif ve postoperatif parametreleri ve taşsızlık oranları karşılaştırıldı.

Bulgular: Gruplar arasında yaş, cinsiyet, vücut kitle indeksi, operasyon öyküsü, operasyon öncesi stent yerleştirilmesi, şok dalga litotripsi hikayesi, üreteral darlık, taş boyutu, akses kılıfı kullanım oranı, tekrar tedavi, ek tedavi taş sayısı ve lokalizasyonu açısından fark yoktu. Stent uygulanan grupta anlamlı olarak operasyon süresi uzun izlendi. Ek tedavileri red etme oranı grup 1'de daha düşük izlendi. İlk ay sonunda taşsızlık oranlar iki grup için benzer olmasına rağmen, ek tedavilerden sonra taşsızlık oranları grup 1'de anlamlı olarak yüksek izlendi.

Sonuç: FURS sırasında stent yerleştirilmesi, rezidüel taşların kalması durumunda son takipte taşsızlık oranın arttırmaktadır.

Anahtar kelime: Stent, böbrek taşı, üreterorenoskopi
${ }^{1}$ Department of Urology, Uludağ University, Faculty of Medicine, Bursa, Turkey.

2 Department of Urology, Istanbul Aydın University, Faculty of Medicine, Istanbul, Turkey.

Ethics Committee Approval: The study wass approved by the local ethical authority.

Etik Kurul Onayı: Çalışma lokal etik komite tarafindan onaylanmıştır.

Conflict of Interest: No conflict of interest was declared by the authors.

Çıkar Çatışması: Yazarlar çıkar çatışması bildirmemislerdir.

Financial Disclosure: The authors declared that this study has received no financial support. Finansal Destek: Yazarlar bu çalıșma için finansal destek almadıklarını beyan etmişlerdir.

Geliş Tarihi / Received: 16.04.2018

Kabul Tarihi / Accepted: 19.06.2018

Yayın Tarihi / Published: 20.07.2018

Sorumlu yazar / Corresponding author:

Gökhun Özmerdiven

İstanbul Aydin University, Faculty of Medicine,

Dept of Urology, 34295, Besyol, Kucukcekmece. İstanbul, Turkey

Phone: +905353586163

Fax: +902129795045

e-mail: gozmerdiven@gmail.com

Copyright $(\mathcal{C}$ ACEM 


\section{Introduction}

Ureteral double-J (D/J) stents are often placed during many urological procedures. Ureteral $\mathrm{D} / \mathrm{J}$ stent placement for urinary diversion could relieve renal obstruction and prevent ureteral stricture while reducing pain and improving stone-free rates. However, the procedure provides no benefits for uncomplicated ureteroscopic lithotripsy with lower urinary tract symptoms [1].

Flexible ureterorenoscopy (FURS) has an increasing role in active treatment of kidney stones with advanced equipment. D/J stent placement after FURS is controversial, however it has been shown that postoperative $\mathrm{D} / \mathrm{J}$ stenting can decrease postoperative pain in FURS $[2,3]$. In non-complicated FURS for a small stone, no D/J stenting is preferred, yet the effect of stenting for stone-free status has not been widely investigated $[2,3]$. One recent study found that ureteral stents did not improve stone-free rates at the postoperative first month and did not decrease operation time [3].

In the treatment of renal stones with FURS, additional treatments just like extracorporeal shock wave lithotripsy (ESWL) and percutaneous nephrolithotomy (PCNL) may be needed for residual fragmentation after FURS treatment. No studies have investigated the effect of stenting on stone-free rates with additional treatment. Our aim was to evaluate the impact of intra-operative stenting on operative time and stone free-rates at the end of the treatment.

\section{Material and Methods}

Following local ethical committee approval, we reviewed medical records of 289 patients who underwent FURS for kidney stones between October 2009 and January 2015 in a single center. Study procedures followed the ethical standards of the Helsinki Declaration and all patients gave written informed consent of this study. Exclusion criteria were malign ureteral stricture $(n=2)$, severe skeletal malformation $(n=16)$, renal unit malformation $(n=46)$, presence of non-opaque renal stones $(\mathrm{n}=18)$, conversion to percutaneous nephrolithotomy (PCNL) $(n=13)$, failure to report for follow-up $(n=109)$ and patients under 18 years old $(n=37)$. Therefore, a total of 47 patients were evaluated after applying exclusion criteria. Patients with $\mathrm{D} / \mathrm{J}$ stent placement after FURS were designated as belonging to the stented group (Group 1) while patients without intra-operative stenting comprised the non-stented group (Group 2).

Patient demographics (age, gender, body mass index (BMI)) and preoperative clinicopathological features including stone location, mean stone area $\left(\mathrm{cm}^{2}\right)$, use of computed tomography, use of preoperative $\mathrm{D} / \mathrm{J}$ stents, previous intervention and surgical treatments for stone disease were recorded. BMI was calculated as weight in kilograms divided by the square of the height in meters. The stone was determined with urinary ultrasound, X-ray of kidney, and ureter and bladder X-rays (Xray KUB). In doubtful cases, a CT scan was performed.

Perioperative data included operation time, operation side, use of ureteral access sheath, and use of D/J stent at the end of the operation. Operation time was also grouped as $<60$ minutes and $\geq 60$ minutes. Hospitalization time (days), Complication rate and patients who had febrile urinary tract infection were recorded.

After the operation, the stone status was evaluated in the second week and in the first month. If any residual stones were observed after the first month, additional treatment had been planned. D/J stent would have removed at the end of the additional treatment. The status of the stones was assessed by physical examination, urinalysis, X-ray KUB and urinary ultrasound. In ambiguous cases, non-contrast computed tomography was used to assess the status. Patients that required additional treatment for residual fragments were evaluated one month following their last procedure. Additional treatments for residual stones were extracorporeal shock wave lithotripsy (ESWL), retrograde intrarenal surgery (RIRS), percutaneous nephrolithotomy (PCNL) and ESWL+RIRS. Patients who refused the additional therapy for residual stones with known final stone status was included the study and they were classified as refused additional treatment.

\section{Flexible ureterorenoscopy (FURS) Technique}

FURS was performed in a dorsal lithotomy position under general anesthesia. Semi-rigid double lumen $8.5 \mathrm{~F}$ ureterorenoscope was used for guide wire insertion and assessment of the ureters. After a guide wire was inserted into the ureter under fluoroscopic image, ureteral obstruction or stones were assessed with visual and fluoroscopic images. A $7.5 \mathrm{~F}$ flexible ureterorenoscope was used. The $9.5 \mathrm{~F}$ access sheath was used according to ureteral diameter and stone burden. Stone fragmentation was performed with holmium laser lithotripsy. The stones were fragmented until they were less than $2 \mathrm{~mm}$ in size. Small fragments were left for spontaneous passage. A $4.7 \mathrm{~F}$ $\mathrm{D} / \mathrm{J}$ stent was inserted at the end of the operation.

\section{Statistical analysis}

Statistical analysis was performed with the SPSS version 22 software. The Shapiro-Wilk test was used to test the normality of variables. The normally distributed variables are presented as mean \pm standard deviation and were compared with Student's $\mathrm{t}$ test. The non-normally distributed variables were presented as median (minimum-maximum) and were compared with the Mann-Whitney U test. Nominal data were presented as number and percentage and were compared to the Fisher's Exact test. A finding of $\mathrm{p}$ less than 0.05 was considered statistically significant.

\section{Results}

The mean age was $49.3 \pm 13.9$ years in group 1 and $47.8 \pm 13.8$ years in group 2 . The rate of preoperative $\mathrm{D} / \mathrm{J}$ stent (prestenting) was $4.3 \%$. The stones were mostly observed in lower pole of kidney (29.2\% in group 1 and $39.1 \%$ in group 2 ) in all groups. ESWL treatment was applied more than other treatments, before FURS $(29.2 \%$ in group 1 and $34.8 \%$ in group 2 ) in all groups. Ureteral stricture was not seen in both groups.

There were no differences between the groups according to age, gender, BMI, operation history, mean stone area, preoperative CT scan, side and localization of the stones, preoperative D/J stent history, previous ESWL, operative history and ureteral stricture ( $\mathrm{p}>0.05$ for all) (Table1).

Use of access sheath rate, need for additional treatments, number of additional treatments and hospitalization time were similar for the two groups (Table 2). Seven patients $(29.1 \%)$ had febrile urinary tract infection in Group 1 and inpatient treatment was applied for one patient because of urosepsis. 4 patients $(17.3 \%)$ had febrile urinary tract infection in Group 2. Overall complication rate are similar in two groups $(\mathrm{p}=0.646)$ (Table 2).

Although refusals of the additional treatment rate were more prevalent in the Group 2, the difference was not statistically significant (Table 2). The stone-free rate was $45.8 \%$ at the first postoperative month and $83.3 \%$ with the additional therapy in Group 1. In Group 2, the stone-free rate was $21.7 \%$ at the first postoperative month and $30.4 \%$ with additional therapy. The stone-free rate in the first month was higher in Group 1, but not statistically significant. However, the stone-free rate after the additional therapy was significantly lower in Group 2 and operation time was significantly higher in Group $1(\mathrm{P}=0.029$ and $\mathrm{P}=0.049$, respectively) (Table 2 ). 
Table 1. Comparison of the patients' demographics and preoperative data.

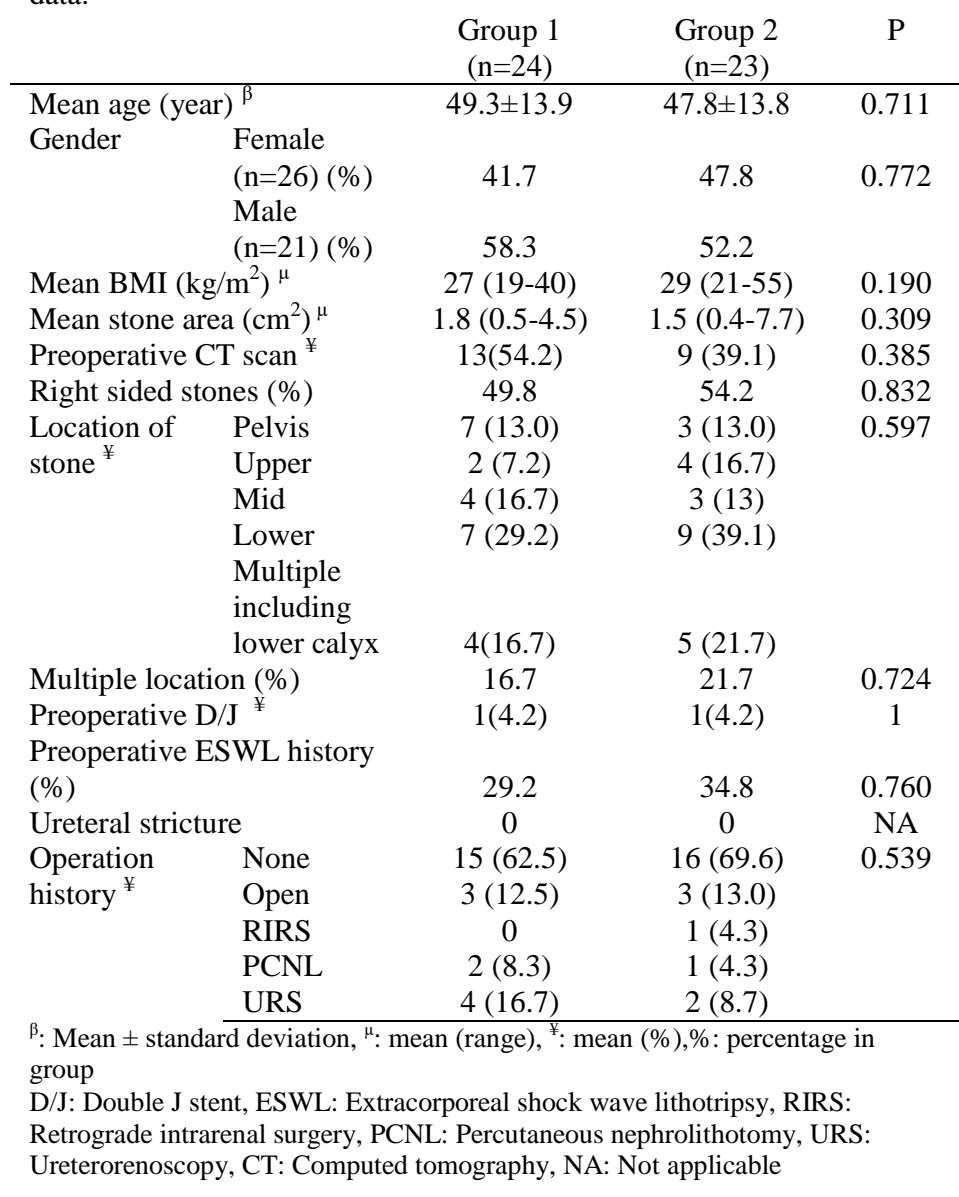

Table 2. Comparison of two groups with respect to the perioperative and follow up parameters.

\begin{tabular}{|c|c|c|c|c|}
\hline & $\begin{array}{c}\text { Group } 1 \\
(\mathrm{n}=24)\end{array}$ & $\begin{array}{c}\text { Group } 2 \\
(\mathrm{n}=23)\end{array}$ & $\mathrm{P}$ \\
\hline Use of acce & leath rate $(\%)$ & 50 & 39.1 & 0.561 \\
\hline \multicolumn{2}{|c|}{ Operative time $(\min )^{\mu}$} & $90(40-170)$ & $55(40-180)$ & 0.049 \\
\hline Operative & $<60 \min$ & $4(16.7)$ & $12(52.2)$ & 0.045 \\
\hline time & $\geq 60 \min$ & $20(83.3)$ & $11(47.8)$ & \\
\hline \multicolumn{2}{|c|}{ Hospitalization time $(\text { day })^{\mu}$} & $2(2-19)$ & $2(2-5)$ & 0.282 \\
\hline \multicolumn{2}{|c|}{ Febrile urinary tract infection ${ }^{*}$} & $7(29.1)$ & $4(17.3)$ & 0.061 \\
\hline \multicolumn{2}{|c|}{ Complication rate $(\%)$} & 29.1 & 26 & 0.646 \\
\hline Additional & None & $20(83.3)$ & $17(73.9)$ & 0.301 \\
\hline \multirow{5}{*}{ treatment ${ }^{*}$} & SWL & $2(8.3)$ & $5(21.7)$ & \\
\hline & RIRS & 0 & $1(4.3)$ & \\
\hline & PCNL & $1(4.2)$ & 0 & \\
\hline & RIRS with & & & \\
\hline & SWL & $1(4.2)$ & 0 & \\
\hline \multicolumn{2}{|c|}{ Total treatment number ${ }^{\mu(\text { (range })}$} & $\begin{array}{l}1.21 \pm 0.72 \\
(1-4)\end{array}$ & $\begin{array}{l}1.26 \pm 0.90 \\
(1-5)\end{array}$ & 0.947 \\
\hline \multicolumn{4}{|c|}{ Refused the additional } & 0.100 \\
\hline \multicolumn{2}{|c|}{ Stone free rate $\left(1^{\text {st }} \text { month }\right)^{¥}$} & $11(45.8)$ & $5(21.7)$ & 0.650 \\
\hline \multicolumn{2}{|c|}{$\begin{array}{l}\text { Stone free rate (at the end of } \\
\text { additional treatment) }{ }^{\ddagger}\end{array}$} & $20(83.3)$ & $7(30.4)$ & 0.029 \\
\hline \multicolumn{5}{|c|}{$\begin{array}{l}{ }^{\beta}: \text { Mean } \pm \text { standard deviation, }{ }^{\mu}: \text { mean (range), }{ }^{*}: \text { mean }(\%), \% \text { : percentage in } \\
\text { group }\end{array}$} \\
\hline
\end{tabular}

\section{Discussion}

Although ureteral stents may support ureteral healing and relieve ureteral obstruction, they cause significant morbidity, including pain, irritating voiding symptoms, hematuria and infection $[4,5]$. For these reasons, routine D/J after FURS stenting is controversial.
The insertion of a D/J stent after URS was widely investigated, contrary to FURS. Routine stenting after ureteroscopy was not shown to improve the stone-free rate when accompanied by increased lower urinary symptoms, pain and operative time [6]. Even a greater stone diameter was not found to be a factor in making a ureteral stenting decision when there were similar stone-free and complication rates after uncomplicated ureteroscopic lithotripsy [7].

Although D/J stent placement at the end of the FURS procedure is optional, nearly $50 \%$ of surgeons prefer to insert it routinely [8]. Others make the decision according to intraoperative factors [8]. Miernik et al. [9] reported that complication rates were found to be $9.1 \%$ due to the use of wider access sheath and so an intraoperative $\mathrm{D} / \mathrm{J}$ stent was inserted in $57 \%$ of patients undergoing FURS.

Nevertheless, a few studies have investigated the effect of intra-operative $\mathrm{D} / \mathrm{J}$ stent placement on the stone-free rate following additional treatment. It was shown that $\mathrm{D} / \mathrm{J}$ stent insertion could lessen the pain in FURS, although there was no benefit for stone free-status at first postoperative month [2, 3]. However ureteral stent could be used for pain relief with a shorter operative time [10]. These studies did not support the use of a D/J stent for all FURS cases. However, these studies also didn't emphasize the role of $\mathrm{D} / \mathrm{J}$ stenting on residual stone treatment after FURS, as is the focus of our study.

Potential benefits of a $\mathrm{D} / \mathrm{J}$ stent are support of the passage of urine and stone fragments and hydronephrosis healing. Jones et al. [11] reported a higher success rate following failed ureteroscopic management of ureteric calculi with ureteral stent insertion. Also, Chu et al. [12] stated that prestenting decreased operative time and the reoperation rate in patients with ureter stones larger than $1 \mathrm{~cm}$. Moreover Lumma et al. [13] reported prestenting improved stone-free rates in patients with mid- or upper-ureter stones as distinct from distal ureter stones. Rubenstein et al. [14] point out prestenting can result in better stone-free rates. Preoperative D/J stent placement also has been shown to improve the success rate for URS for nephroureterolithiasis [15]. Preoperative ureteral stenting may facilitate the ureteral access sheath insertion [16]. These studies could explain the better stone-free rate at the end of additional therapy in patients with perioperative stenting. However, stenting before SWL did not increase the stone-free rate with lower urinary tract symptoms [17].

It has been reported that stenting after ureteroscopic stone management caused longer operative time [6]. However stenting after FURS led to the shorter operative times in the previous research [3], in our study operative time was longer in group 1 .

Patient compliance is essential for FURS because retreatment and additional treatment are required, especially for large stones. The rate of refusals of additional treatment was higher in group $2(12.5 \%$ vs. $4.2 \%)$ but the difference was not statistically significant. Stone-free rate with an additional treatment was significantly higher in group 1 . So, we believe that stenting encouraged patients to seek further treatment and stenting should be the part of minimal invasive surgery for kidney stones, if additional treatments are necessarily considered.

As the limitation of this study, the exclusion criteria were too many, but the exclusion criteria had a high stent placement rate. Therefore, a comparable small sample size has been realized.

In conclusion, stenting intraoperatively after FURS improved the stone-free rate on the final follow-up. However, stenting caused the prolonged operative time. We suggest that intraoperative stenting after FURS is on surgeon's mind if 
surgeon consider that residual stones will be at the end of the first month. Prospective studies with a larger number of patients could give a definite judgment on these issues.

\section{References}

1. Pengfei S, Yutao L, Jie Y, Wuran W, Yi D, Hao Z, et al. The results of ureteral stenting after ureteroscopic lithotripsy for ureteral calculi: a systematic review and meta-analysis. J Urol. 2011;186:1904-9.

2. Torricelli FC, De S, Hinck B, Noble M, Monga M. Flexible ureteroscopy with a ureteral access sheath: when to stent? Urology. 2014;83:278-81.

3. Ozyuvali E, Resorlu B, Oguz U, Yildiz Y, Sahin T, Senocak C, et al. Is routine ureteral stenting really necessary after retrograde intrarenal surgery? Arch Ital Urol Androl. 2015;87:72-5.

4. Fiuk J, Bao Y, Calleary JG, Schwartz BF, Denstedt JD. The use of internal stents in chronic ureteral obstruction. J Urol. 2015;193:1092100.

5. Mendez-Probst CE, Fernandez A, Denstedt JD. Current status of ureteral stent technologies: comfort and antimicrobial resistance. Curr Urol. Rep 2010;11:67-73.

6. Song T, Liao B, Zheng S, Wei Q. Meta-analysis of postoperatively stenting or not in patients underwent ureteroscopic lithotripsy. Urol Res. 2012;40:67-77.

7. Picozzi SC, Ricci C, Stubinski R, Casellato S, Ratti D, Macchi A, et al Is stone diameter a variable in the decision process of employing a ureteral stent in patients undergoing uncomplicated ureterorenoscopy and associated intracorporeal lithotripsy? World J Urol. 2013;3:1617-25.

8. Sanguedolce F, Liatsikos E, Verze P, Hruby S, Breda A, Beatty JD, et al. Use of flexible ureteroscopy in the clinical practice for the treatment of renal stones: results from a large European survey conducted by the EAU Young Academic Urologists-Working Party on Endourology and Urolithiasis. Urolithiasis. 2014;42:329-34.

9. Miernik A, Wilhelm K, Ardelt PU, Adams F, Kuehhas FE, Schoenthaler M. Standardized flexible ureteroscopic technique to improve stone-free rates. Urology. 2012;80:1198-202.

10. Cerruti A, Lebdai S, Martin F, Hoarau N, Chautard D, Culty T, et al. Do postoperative drainage types modify outcomes after retrograde intrarenal surgery? Prog Urol. 2015;25:331-5.

11. Jones BJ, Ryan PC, Lyons O, Grainger R, McDermott TE, Butler MR. Use of the double pigtail stent in stone retrieval following unsuccessful ureteroscopy. Br J Urol. 1990;66:254-56.

12. Chu L, Sternberg KM, Averch TD. Preoperative stenting decreases operative time and reoperative rates of ureteroscopy. J Endourol. 2011;25:751-4.

13. Lumma PP, Schneider P, Strauss A, Plothe KD, Thelen P, Ringert RH, et al. Impact of ureteral stenting prior to ureterorenoscopy on stone-free rates and complications. World J Urol. 2013;3:855-9.

14. Rubenstein RA, Zhao LC, Loeb S, Shore DM, Nadler RB. Prestenting improves ureteroscopic stone-free rates. J Endourol. 2007;21:1277-80.

15. Netsch C, Knipper S, Bach T, Herrmann TR, Gross AJ. Impact of preoperative ureteral stenting on stone-free rates of ureteroscopy for nephroureterolithiasis: a matched-paired analysis of 286 patients. Urology. 2012;80:1214-19.

16. Mogilevkin Y, Sofer M, Margel D, Greenstein A, Lifshitz D. Predicting an effective ureteral access sheath insertion: a bicenter prospective study. J Endourol. 2014;28:1414-17.

17. Shen P, Jiang M, Yang J, Li X, Li Y, Wei W. Use of ureteral stent in extracorporeal shock wave lithotripsy for upper urinary calculi: a systematic review and meta-analysis. J Urol. 2011;186:1328-35. 